\title{
Effect of Different Rice Straw Management Strategies for Sustainable Weed Management in Transplanted Rice
}

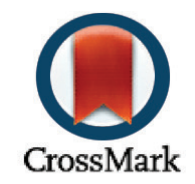

\section{K. Arivukkarasu, S. Arivazhagan}

Department of Agronomy, Faculty of Agriculture, Annamalai University, Chidambaram, Tamil Nadu, India

\begin{abstract}
Field experiments were conducted at the experimental farm, Department of Agronomy, Annamalai University in Samba (September-January) season, to study the effect of off-season land management practices with weed control measures on the weed flora and crop performance of rice. Off-season land management practices and crop weed control measures had significant interaction on weed parameters and crop parameters. Incorporation of rice straw at $5 \mathrm{t} / \mathrm{ha}$ in the field in 40 days before transplanting in the preceding off-season followed by hand weeding twice in the succeeding rice crop performed significantly superior with the least weed dry matter production, highest weed control index, and highest grain yield. However, this was on par with the treatments, namely, incorporation of rice straw at $5 \mathrm{t} / \mathrm{ha}$ in the preceding off-season followed by post-emergence application of bispyribac sodium at $0.035 \mathrm{~kg} / \mathrm{ha}$ and by incorporation of rice straw at $5 \mathrm{t} /$ ha in the preceding off-season followed by post-emergence application of bispyribac sodium at $0.025 \mathrm{~kg} / \mathrm{ha}$ instead of straw burning in rice crop. Hence, the study reveals that integration of rice straw incorporation at $5 \mathrm{t} / \mathrm{ha}$ in the preceding season as off-season land management practice, followed by any one of the weed control measures i.e. either by hand weeding twice or by post-emergence application of bispyribac sodium at $0.035 \mathrm{~kg} / \mathrm{ha}$ or by postemergence application of bispyribac sodium at $0.025 \mathrm{~kg} / \mathrm{ha}$ in the succeeding rice crop could be a sustainable weed management strategy in transplanted rice, instead of rice straw removal or rice straw burning.
\end{abstract}

Address for correspondence: Dr. K. Arivukkarasu, Assistant professor, Department of Agronomy, Faculty of Agriculture, Annamalai University, Chidambaram, Tamil Nadu, India

Keywords:

Bispyribac sodium, Rice, Rice straw, Weed management

Received: $08^{\text {th }}$ March 2019 Accepted: 09 ${ }^{\text {th }}$ March 2019 Published: $21^{\text {rd }}$ March 2019

\section{INTRODUCTION}

Rice crop suffers from various biotic and abiotic production constraints. In transplanted rice, weed competition is one of the yield limiting biotic constraints that affected the productivity up to $30-50 \% .^{[1]}$ Although hand weeding was more effective in controlling weeds in transplanted rice, it was expensive, time-consuming difficult, and often limited by the scarcity of laborers in time. On the other hand, herbicides offer economic and efficient weed control. ${ }^{[2]}$ However, sole dependence and continuous use of herbicides resulted in weed shift. In India, rice straw is either removed from the field, burnt in the field, or incorporated in the soil and these practices were observed to influence the weeds in the succeeding crops.. ${ }^{[3]}$ In this situation, exploring the complementary effect from off-season land management such as straw management integrated with weed management practices such as hand weeding and herbicides on weeds in succeeding rice crop may offer useful lead in sustainable weed management in transplanted rice.

\section{MATERIALS AND METHODS}

Field experiments were conducted at the experimental farm, Department of Agronomy, Annamalai University in Samba (September-January) during 2013-2014 to find out the performance of different weed management practices in transplanted rice. The experiments were conducted at the experiment farm, Department of Agronomy, Annamalai University. The experiment was conducted in a split-plot design which was replicated thrice. In the preceding offseason, the experimental field was laid out into strips of $25 \times 5 \mathrm{~m}$ size, and off-season treatments were taken up individually in separate strips with three main treatments. In the treatment $\left(\mathrm{M}_{1}\right)$ rice straw incorporation in the off-season, the straw was incorporated at $5 \mathrm{t} / \mathrm{ha}$ in the field in 40 days before transplanting, and in $\mathrm{M}_{2}$ rice, the straw was burnt in the preceding off-season. In the off-season fallow treatment $\left(\mathrm{M}_{3}\right)$, the straws were removed and the field strip was left without any disturbance. In the ensuring rice crop, each strip that received a particular off-season treatment was superimposed with crop weed control practices with six subtreatments, namely 
Table 1: Effect of off-season land management and weed control measures on weed parameters and grain yield in rice

\begin{tabular}{|c|c|c|c|}
\hline Treatments & $\begin{array}{l}\text { Weed dry matter production on } \\
60 \mathrm{DAT}(\mathrm{kg} / \mathrm{ha})\end{array}$ & $\begin{array}{l}\text { Weed control } \\
\text { Index }(\%)\end{array}$ & Grain yield (t/ha) \\
\hline \multicolumn{4}{|l|}{ Main treatments (Off-season) } \\
\hline $\mathrm{M}_{1}$ - Incorporation of rice straw & 438.80 & $63.49(80.09)$ & 4.34 \\
\hline $\mathrm{M}_{2}-$ Burning of rice straw & 503.48 & $61.45(77.16)$ & 3.92 \\
\hline Off-season M3 - Straw removed (fallow) & 747.98 & - & 2.92 \\
\hline $\mathrm{CD}(P=0.05)$ & 43.78 & 3.01 & 0.51 \\
\hline \multicolumn{4}{|l|}{ Sub treatments (rice crop) } \\
\hline $\mathrm{S}_{1}$ - Unweeded control & 1660.15 & - & 1.80 \\
\hline $\mathrm{S}_{2}-$ Two hand weeding (20 and 40 DAT) & 275.51 & $68.86(87.46)$ & 4.63 \\
\hline $\mathrm{S}_{3}-$ Butachlor at $1.25 \mathrm{~kg} / \mathrm{ha}$ (pre) & 449.38 & $62.72(79.66)$ & 3.18 \\
\hline $\mathrm{S}_{4}-$ Bispyribac sodium at $0.015 \mathrm{~kg} / \mathrm{ha}$ (post) & 372.20 & $64.89(82.97)$ & 3.46 \\
\hline $\mathrm{S}_{5}-$ Bispyribac sodium at $0.025 \mathrm{~kg} / \mathrm{ha}$ (post) & 322.50 & $67.21(85.51)$ & 4.34 \\
\hline $\mathrm{S}_{6}-$ Bispyribac sodium at $0.035 \mathrm{~kg} / \mathrm{ha}$ (post) & 300.79 & $68.02(86.30)$ & 4.47 \\
\hline $\mathrm{CD}(P=0.05)$ & 47.32 & 3.45 & 0.52 \\
\hline
\end{tabular}

Table in parenthesis are original values

the unweeded control $\left(\mathrm{S}_{1}\right)$ and hand weeding which was done once at 20 days after transplanting (DAT) and again at 40 DAT in the treatment with two hand weeding $\left(\mathrm{S}_{2}\right)$. In treatment $\left(\mathrm{S}_{3}\right)$ Pre-emergence application of butachlor at $1.25 \mathrm{~kg} / \mathrm{ha}$ was done and the formulation used was 50\% EC. In treatment $\left(\mathrm{S}_{4}\right)$ post emergence application of bispyribac sodium at $0.015 \mathrm{~kg} / \mathrm{ha}$, in treatment (S5 ) post emergence application of bispyribac sodium at $0.025 \mathrm{~kg} / \mathrm{ha}$ and in treatment (S6 ) post emergence application of bispyribac sodium at $0.035 \mathrm{Kg} / \mathrm{ha}$ was used and for all the bispyribac sodium treatments the formulation used was $10 \%$ SC The individual plot size for subtreatments was $5 \times 4 \mathrm{~m}$ size. For herbicide treatments, pre-emergence application was taken up on the $3^{\text {rd }}$ day after transplanting and post-emergence application on 20 DAT with $500 \mathrm{~L}_{\text {of }}$ water ha-1 through knapsack sprayer fitted with flood jet nozzle in the morning hours maintaining a thin film of water column $(1 \mathrm{~cm})$. The plots were left without irrigation or drainage for $48 \mathrm{~h}$ after spraying. All the treatments were imposed uniformly in Samba season. The data involving percentage values were transformed by angular transformations for analysis.

\section{RESULTS AND DISCUSSION}

In the experimental fields, the weed species, namely Cyperus difformis, Cyperus rotundus, Leptochloa chinensis, and Echinochloa colonum, contributed largely for the total weed count in both the seasons and were found to be significantly influenced by the treatments in both the seasons. Marsilea quadrifolia, Bergia capensis, and Eclipta alba occurred in negligible proportion, and the influence of treatments on these weeds was not significant. Among the off-season land management practices as main treatments, incorporation of rice straw in the preceding off-season was observed to be superior in reducing the weed dry matter production of the succeeding rice crop, as evidenced by the least weed dry matter production with highest weed control index and yield [Table 1]. This could be due to the release of phytotoxic compounds by rice straw that has the ability to accumulate in sufficient amounts that persist in the soil and might have caused a remarkable reduction in weed growth as reported by Devasinghe et al. ${ }^{[4]}$

Among the rice weed control measures compared as subtreatments, hand weeding twice during the cropping period recorded the least weed dry matter production and highest weed control index. The superior performance of twice hand weeding could be attributed to manual removal of existing vegetation of all the weeds without sparing any one of the individual ones. This was on par with the following treatments with post-emergence application of bispyribac sodium at $0.035 \mathrm{~kg} / \mathrm{ha}$ and post-emergence application of bispyribac sodium at $0.025 \mathrm{~kg} / \mathrm{ha}$. This could be attributed to the fact that bispyribac sodium is a pyrimidinyl carboxy herbicide that inhibits the plant enzyme acetolactate synthase, and thereby aminoacid synthesis was inhibited and ultimately cause death of weeds. As the herbicide is effective against broad spectrum of weeds in rice, the same might have contributed for effective control of weeds in later stages of the crop. This is in line with the reports of Veerapathran and Balasubramanian. ${ }^{[5]}$

The interaction effect between off-season land management practices (main treatments) and crop weed control measures (subtreatments) was observed to show significant interaction on weed parameters and grain yield [Table 1]. Incorporation of rice straw in the preceding off-season followed by hand weeding twice performed significantly superior with the least weed dry matter production, highest weed control index, and maximum grain yield. This was on par with incorporation of rice straw in the preceding off-season followed by postemergence application of bispyribac sodium at $0.035 \mathrm{~kg} / \mathrm{ha}$ and incorporation of rice straw in the off season followed by postemergence application of bispyribac sodium at $0.025 \mathrm{~kg} / \mathrm{ha}$. Integration of off-season land management with better weed control measures during critical stages of the crop achieved a prolonged depletion of weed population contributed for the superior performance of these treatments. These observations are in concomitance with the findings of Rawat et al. ${ }^{[6]}$ and Prakash et al. ${ }^{[7]}$ 


\section{CONCLUSION}

On the basis of the study, it can be concluded that incorporation of rice straw at $5 \mathrm{t} / \mathrm{ha}$ in the preceding offseason reduced weed infestation in the succeeding rice crop instead of rice straw removal or rice straw burning in offseason. Hence, integration of incorporation of rice straw at $5 \mathrm{t} / \mathrm{ha}$ followed by weed control either with hand weeding twice or post-emergence application of bispyribac sodium at $0.035 \mathrm{~kg} / \mathrm{ha}$ or post-emergence application of bispyribac sodium at $0.025 \mathrm{~kg} / \mathrm{ha}$ could be a sustainable weed management strategy in transplanted rice.

\section{REFERENCES}

1. Nagarajan R, Chinnusamy C. Evaluation of bensulfuron methyl and butachlor on weed control and productivity of transplanted rice (Oryza sativa L.). In: Proceedings of Weed Science Conference. $30^{\text {th }}$ November and $1^{\text {st }}$ December. Coimbatore: TNAU; 2010. p. 145.

2. Kumar M, Sharma G. Efffect of herbicides alone and in combination on direct seeded Rice. Indian J Weed Sci 2005;37:197-201.

3. Khankhane PJ, Baarman KK, Jay GV. Effect of rice residue management practices on weed density wheat productivity and soil fertility in a swell-shrink soil. Indian J Weed Sci 2009;41:41-5.

4. Devasinghe DA, Premarathne KP, Sangakkara VR. Weed management by rice straw mulching in direct seeded lowland rice (Oryza sativa L.). Trop Agric Res 2011;22:263-72.

5. Veerapathran R, Balasubramanian R. Evaluation of bispyribacsodium in transplanted rice. Indian J Weed Sci 2013;45:12-5.

6. Rawat CS, Chaudary CB, Upadhyaya VB, Jain V. Efficiency of bispyribac-sodium on weed flora and yield drilled rice. Indian $\mathrm{J}$ Weed Sci 2012;44:183-58.

7. Prakash C, Shivram RK, Koli NR. Bioefficacy of new herbicides in transplanted rice. Indian J Weed Sci 2013;45:282-4.

Cite this article: Arivukkarasu K, Arivazhagan S. Effect of Different Rice Straw Management Strategies for Sustainable Weed Management in Transplanted Rice. Asian J Mult-Disciplinary Res. 2019;5(1):5-7.

Source of Support: Nil, Conflict of Interest: None declared. 